\title{
Land use/land cover patterns and challenges to sustainable management of the Mono transboundary biosphere reserve between Togo and Benin, West Africa
}

\author{
Kossi ADJONOU ${ }^{1 *}$, Issa Adbou-Kérim BINDAOUDOU ${ }^{2}$, Kossi Novinyo SEGLA ${ }^{1}$, \\ IDOHOU Rodrigue ${ }^{3}$, Kolawole Valère SALAKO ${ }^{3}$, Romain GLELE-KAKAII ${ }^{3}$ and \\ Kouami KOKOU $^{1}$ \\ ${ }^{1}$ Faculté des Sciences, Université de Lomé ; 01 BP : 1515 Lome, Togo. \\ ${ }^{2}$ Centre Universitaire de Recherche et d'Application en Télédétection, Université Félix HOUPHOUËT- \\ BOIGNY, 01 BPV 34 Abidjan 01, Abidjan, Côte d'Ivoire. \\ ${ }^{3}$ Faculté des Sciences Agronomiques, Université d'Abomey-Calavi, 03 B.P. 2819, Cotonou-Bénin. \\ *Corresponding author; E-mail: kossiadjonou@hotmail.com
}

\section{ACKNOWLEDGMENTS}

This work was supported by: Central and West African Forest Space Observation Project (OSFACO) of Research Institute for Development (IRD) and French Agency for Development (AFD); Mono Delta Transborder Biosphere Reserve Project between Togo and Benin (ProMono) of the German international cooperation agency for international development (Deutsche Gesellschaft für Internationale Zusammenarbeit GIZ) for funding this research.

\section{ABSTRACT}

The Mono Transboundary Biosphere Reserve (RBTM) has significant resources but faces many threats that lead to habitat fragmentation and reduction of ecosystem services. This study, based on satellite image analysis and processing, was carried out to establish the baseline of land cover and land use status and to analyze their dynamics over the period 1986 to 2015. The baseline of land cover established six categories of land use including wetlands (45.11\%), mosaic crops/fallow (25.99\%), savannas (17.04\%), plantation $(5.50 \%)$, agglomeration/bare soil $(4.38 \%)$ and dense forest $(1.98 \%)$. The analysis of land use dynamics showed a regression for wetlands (-23\%), savannas $(-16.06 \%)$ and dense forest $(-7.60 \%)$. On the contrary, occupations such as mosaic crops/fallow land, urban agglomerations/bare soil and plantation increase in area estimated at respectively $128.64 \%, 93.94 \%$ and $45.23 \%$. These results are of interest to stakeholders who assess decisions affecting the use of natural resources and provide environmental information essential for applications ranging from land-use planning, forest cover monitoring and the production of environmental statistics.

(C) 2020 International Formulae Group. All rights reserved.

Keywords: Land use, baseline, spatial dynamics, environmental statistics, ecological monitoring.

\section{INTRDUCTION}

In recent decades, sub-Saharan Africa has experienced major environmental problems, including deforestation reflecting the conversion of forest to non-forest lands.
Vegetation cover conversions and changes in land use patterns are identified as the major drivers of global environmental change (Minta et al., 2018; Zoungrana et al., 2018). These conversions, including changes of forest and / 
or woodlands to agricultural lands, have negative effects on climate, terrestrial carbon stores, and loss of biodiversity (Muriuki et al., 2011; Dube and Mutanga, 2015; Sibanda et al., 2018). They also result in the fragmentation of wildlife habitats and disruption of ecological and hydrological processes (Liu et al., 2008). In other cases, conversions have resulted in increased land surface temperatures and soil erosion, decreased evaporation rates and precipitation, and changes in rainfall patterns (Bounoua et al., 2002).

These observations are true in areas of high population density marked by contrasting climatic conditions and high demand for arable land. These characteristics are observed in the Mono Transboundary Biosphere Reserve (RBTM) located in the Dahomey corridor on the southern border between Benin and Togo (Kokou et Sokpon, 2006). This area is rich in plant and animal resources associated with different multi-functional ecosystems (Kokou et Sokpon, 2006; Adjonou et al., 2017). These ecosystems are unique habitats in the heavily anthropized region and are the last refuge for different type of wildlife in the Guineo-Congolese zone sheltering species such as hippopotamus, buffalo, small antelopes, monkeys, reptiles threatened with extinction. For example the red-bellied monkey (Cercopithecus erythrogaster erythrogaster Gray) is endemic to the area (Hougbédji et al., 2012; Agbessi et al., 2017).

However, many factors threaten biodiversity within and around this reserve. These include the uncontrolled exploitation of forest resources, fragmentation of habitats, pollution and changes in climatic parameters (Avakoudjo et al., 2014; Kpedenou et al., 2016; Akobi et al., 2018). These factors put great pressure on the dynamics of land cover and land use. Considering and mastering these factors will allow the effective conservation of the RBTM ecosystems and associated biodiversity. Unfortunately, the RBTM ecosystems, their dynamics, habitats and landuse patterns in the area are poorly documented
(Bouko et al., 2007). In addition, there is no reference situation based on scientific data in terms of land use on the reserve. This information is needed to ensure sustainable management of the RBTM.

In the RBTM landscape, studying the nature, extent, and structure of land conversions, allows understanding the changes in forest cover and their consequences to be evaluated in order to develop sustainable strategies for biodiversity conservation. Land cover dynamics and land use are essential inputs for establishing a reliable environmental database for applications ranging from the production of environmental statistics, monitoring of forest cover, identification of biodiversity conservation sites, assessment of land degradation index and modeling of spatial dynamics for making future projections (Oloukoi et al., 2006; Bouko et al., 2007; Padonou et al., 2017). Based on remote sensing technologies and satellite data coupled with field investigations, this paper is aimed at: (i) establishing a land cover and a land use baseline for the RTBM, and (ii) analyzing the dynamics of land-use patterns in the period 1986 to 2015 in this area allowing to evaluate different trends in the evolution of the natural landscape.

\section{MATERIALS AND METHODS \\ Study area}

The RTBM is located on land at the southern border between Benin and Togo. It is located between $6^{\circ} 8$ '52.8 "and $7^{\circ} 3^{\prime} 41.8^{\prime \prime}$ North latitude and between $1^{\circ} 24$ ' 18.2 "and 1 ${ }^{\circ} 30^{\prime} 0.0^{\prime \prime}$ East longitude (Figure 1) and covers $345.22 \mathrm{~km}^{2}$. The reserve is located in the dry dahomey corridor characterized by mosaics of dense semi-deciduous forests, guinean savannas, marshy meadows, marshes, mangroves and water plans, crops and fallows mosaics in the Dahomey Gap (Kokou et Sokpon, 2006).

According to the Köppen-Gieger, climate classification system, the RTBM is characterized by a humid tropical climate with 
a succession of four seasons per year, two dry seasons the first from November to March and the second from July to September and two rainy seasons from March to July and from September to November. Annual rainfall varies between $850 \mathrm{~mm}$ and $1250 \mathrm{~mm}$ with a monthly average maximum of about 222.57 $\mathrm{mm}$ during the long rainy season and 88.30 $\mathrm{mm}$ during the short rainy season (October). The average maximum temperature is 31.25 ${ }^{\circ} \mathrm{C}$ between December and April, and the minimum temperature is $28{ }^{\circ} \mathrm{C}$ between July and September.

One of the ecological peculiarities of the area is the meeting of different ecosystems, marine, terrestrial and lagoonal. The Mono River is the main river around which the reserve is built. Topographically, the Mono River cuts through the Continental Terminal geological Formation and flows into a wide alluvial valley. Because of the diminishing slope of the river bed, (0.06 to 0.4 $\mathrm{m} / \mathrm{km}$ ), the Mono describes large meanders through flood plains before joining the lagoon system near the coast. The littoral part of the reserve consists of two low sandbanks separating the sea from the mainland.

Regarding the cultural and social aspects, the area shelters a population of about two million inhabitants about $80 \%$ of which live on small-scale farming, small-scale fishing and the exploitation of wood and charcoal, and so depend largely on the provision of ecosystem services to the surrounding areas (World Bank, 2017). This area with a high population density, resulting from different waves of migration, is characterized by ethnic and cultural tensions that are reinforced by the poverty of the region.

\section{Methodological steps \\ Data sources}

Two data sources were used to establish the MTBR baseline and the analysis of land-use unit dynamics. These include two Landsat satellite images (TM (1986) and ETM $+(2000))$ and a Sentinel 2A satellite image
(2015 is considered the reference year). The scenes were chosen during the dry season when cloud cover is reduced to a minimum because of phenological phase variations of vegetation (Clerici et al., 2007). Satellite images have also been used with cartographic data consisting of a georeferenced digital layers of Togo and Benin mainly comprising roads, administrative units and localities in both countries. GPS data from the field and Google Earth Pro were also used to complete the information.

\section{Data processing and analysis}

Satellite image processing

- Several steps were followed during the processing of satellite images (Figure 2): Pre-treatment of images: Firstly, the radiometric correction of Landsat TM, ETM + and Sentinel 2A images was used to correct any atmospheric bias and to change from a pixel value to a digital count as a reflectance value. This operation is completed by mosaicing the two Sentinel 2A image scenes to obtain a single scene that can be used to extract the study area more easily;

- Color composites: after several combinations, the color composition of bands 4-5-7 was chosen for the TM and ETM + images and the 4-3-2 bands for the Sentinel 2A image, because it presents the best discriminations of land cover types (Sarr, 2009). This operation is completed by selecting training sites. This involved identifying and delineating about 100 plots representing all types of land cover on the TM and ETM + color compositions of the 4-5-7 bands and the 4-3-2 bands of the Sentinel 2A image. These sites were chosen according to their spatial distribution;

- Classification and accuracy assessment: it consisted in transforming the images into a thematic map. The spectral properties were used to classify the different objects of the image into thematic classes. To do this, the 
supervised classification was adopted (due to a good knowledge of the study area) using the maximum likelihood algorithm that was used for the 1986, 2000 and 2015 images from the colored composition chosen for this purpose. Finally, the accuracy of the classifications obtained was evaluated using a confusion matrix or contingency table obtained from field truth data (collected using GPS) and a representative of each occupation class. soil class;

- Validation of the classification: two classification validation indices were calculated; this includes the overall accuracy (characterizes the proportion of well-ranked pixels, calculated as a percentage and the Kappa index (characterizes the ratio between the wellranked pixels and the total pixels surveyed (Skupinski et al., 2009). In addition to these indices, the field truth data were used for validation.

\section{Dynamics of land cover and land use analysis}

In order to better characterize the dynamics of land use and the transitions between the different thematic classes from one year to the next, a quantitative analysis was carried out. Through a post-classification comparison, the quantitative analysis of changes over the study period was carried out to identify the different changes in land cover and land use classes. It produces a change detection matrix resulting from the comparison between the pixels of the classifications between two dates (Girard et Girard, 1999). This analysis is done by calculating the rate of change (Rc) commonly used in land-use change studies (FAO, 1996; Achard et al., 2002).
This rate is evaluated using the following formula: $\mathbf{R c}=[(\mathbf{S 2} / \mathbf{S 1}) \mathbf{1} / \mathbf{d}-\mathbf{1}] \mathbf{x}$ $\mathbf{1 0 0}$ (where: $R c=$ rate of change $(\%) ; \mathbf{S 1}=$ area of the class on the date $d 1 ; \mathbf{S} \mathbf{2}=$ area of the class on the date $d 2(d 2>d 1)$ et $\boldsymbol{d}=$ number of years between the two dates). Positive values indicate "progression" and negative values "regression". Values close to zero indicate that the class is relatively "stable".

The average annual rate of forest degradation (Kamungandu, 2009) is evaluated from the formula: $\mathrm{ARD}=(\mathbf{S} 2 / \mathbf{S 1}) / \mathbf{d} \times \mathbf{x 1 0 0}$ (where: $A R D=$ average annual rate of degradation (\%); $\mathbf{S 2}=$ Total area of lost forest $; \boldsymbol{S 1}=$ Initial area of forest and $\boldsymbol{d}=$ number of years between the two dates).

The development of the transition matrix made it possible to highlight in a condensed way the different forms of conversion undergone by the units of soil occupation between two dates $\mathrm{d} 1$ and $\mathrm{d} 2$, and to describe the changes that occurred (Schlaepfer et al., 2002). It is obtained by superposing the land use maps of 1986, 2000 and 2015, made possible by the "Intersect polygons" algorithm of the Geoprocessing extension under ArcGIS 10.0.

The analysis of the evolution of the trajectories of changes in the units of occupation of the soil is based on three main scenarios. These are "modifications" and "conversions" of the units that oppose "unchanged" situations. "Modification", means the changes occurring within the same category of land use, for example shrub savannas which becomes shrub steppe or vice versa. Whereas "conversion" is the transition from one category to another, for example forest lands to cultivated areas. The term "unchanged" refers to all classes that remained in the same class between the two dates of the study, that is, not affected by the conversions. 


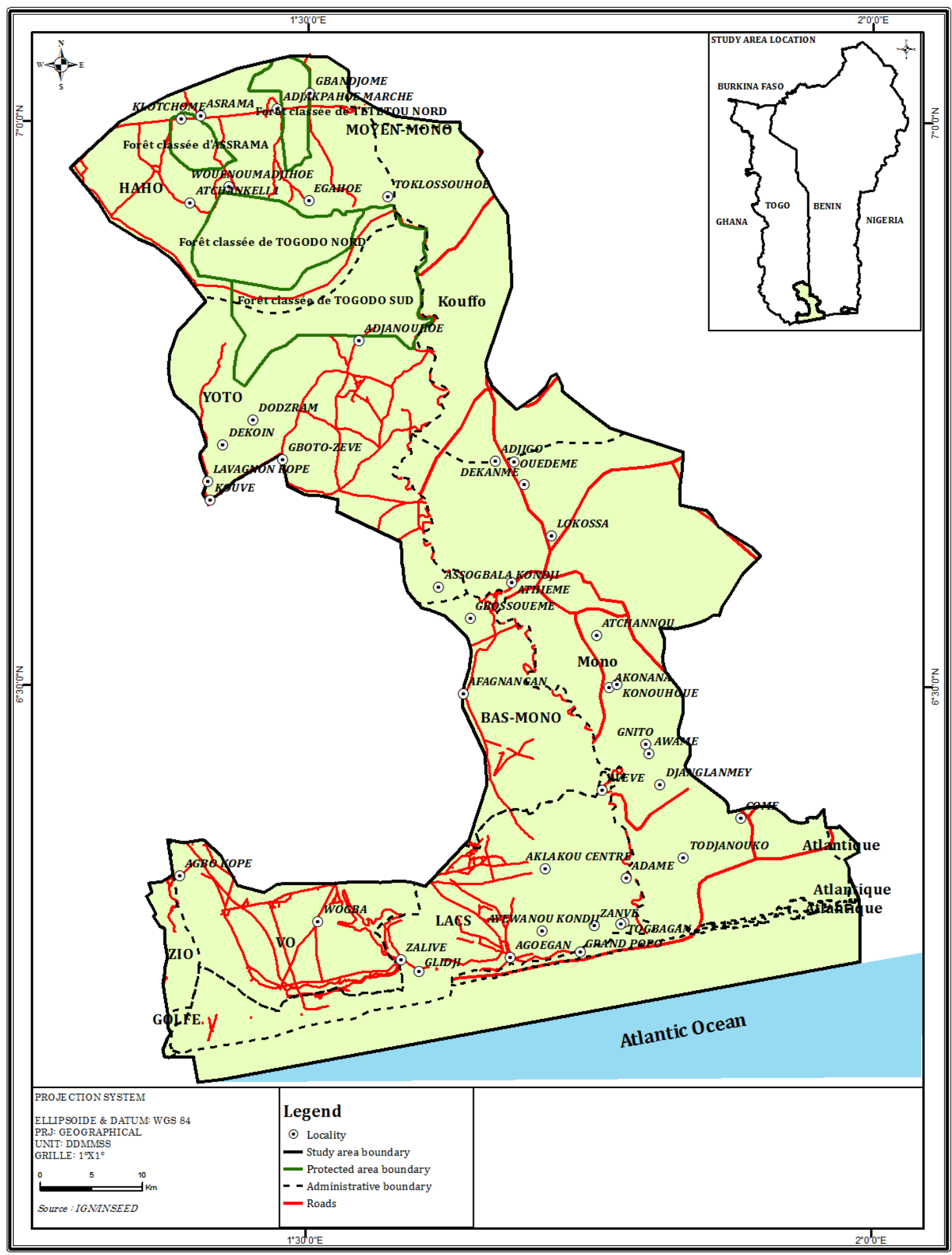

Figure 1: Location of the Mono Transboundary Biosphere Reserve. 


\section{RESULTS}

\section{Land cover in the Mono transboundary biosphere reserve: baseline in 2015}

The results of the processing of Sentinel 2A satellite images for year 2015 to establish the baseline situation of the Mono Transboundary Biosphere Reserve (MTBR) are obtained with an overall accuracy of $89.84 \%$ and an estimated Kappa index at 0.88 . Thus, six (06) main units of land cover are defined. These include (Table 1, Figure 2):

Closed forest : they are composed of dense semi-deciduous forests, dry dense forests, open forests and forest galleries covering 6835 ha (1.98\%); these forests are in the form of fragmented islands dispersed in the reserve and the most important fragments in terms of surface area are observed in the Togodo protected area complex in Togo; the forest galleries identified sometimes appear very dense but narrow on both banks of rivers, notably the forest gallery along the Mono river and the other riparian forests on the banks of other rivers;

Savannas: these are tree and shrub savannas with a large proportion relatively well preserved in the Togodo protected area. They occupy 58919 ha, i.e. $17.0 \%$ of the reserve;

- Mosaic of crops and fallows: they consist of areas of crops and areas previously cultivated and abandoned or invaded by exogenous species. These mosaic of crops and fallows are found throughout the area and occupy 89848 ha representing $25.99 \%$ of the reserve;

Wetlands: the wetlands include mangroves, floodplain savannas dominated by Mitragyna inermis, marshy meadows and bodies of water. They are located in Togo in the Lama, Mono, Haho, Zio floodplains in Togo and in the Mono, Ouémé, Couffo and Zou depressions in Benin. The vast majority of wetlands and their associated plant communities are located in the southern half of the reserve and cover 155944 ha or $45.11 \%$ of the reserve;
Within these wetlands, mangroves that constitute particular ecosystems occupy 83 ha $(0.02 \%$ of reserve);

- Plantations: these are forest tree plantations of teak (Tectona grandis), Khaya senegalensis and Eucalyptus sp., palm (Elaeis guinensis) and coconut (Cocos nucifera). These plantations cover 19028 ha $(5.50 \%)$; forest plantations are plots of variable size (1 ha to a few 2 ha) scattered throughout the reserve. Regarding palm plantations, their cultivation is much practiced in this area and they sometimes occupy large areas approaching hundreds of hectares, like the industrial palm plantation located near Lokossa in Benin and the palm plantation around Kouvé in Togo. Coconut plantations are found mainly in the southern part of the reserve along the coastline in both Togo and Benin;

- Urban agglomerations and bare soil: this unit includes towns, villages and areas with very low vegetation cover, including quarries (sand and gravel) and rocky outcrops. Densely populated urban agglomerations, are concentrated in the southern part of the reserve along the coast. Some big villages are found in the center of the reserve. They occupy 15 148 ha or $4.38 \%$ of the reserve.

\section{Spatio-temporal dynamics of land cover in the reserve between 1986 and 2015}

The evolution of the land cover units in the MTBR is established by the superposition of the maps of three different dates namely 1986, 2000 and 2015 and their respective statistics. Crossing this information shows that the area has undergone significant changes in land use over the 30- year period considered (Table 2, Figure 3).

- Closed forest and savannas showed declines in areas between 1986 and 2015, from respectively 7661 ha to 6835 ha (representing a regression rate of $7.61 \%$ ) and 72695 ha to 58919 ha (a regression of $16.06 \%$ ). The regressive dynamics observed with these two types of land cover is explained by the 
different forms of anthropic pressure that they have undergone in recent years;

- Wetlands including mangroves, marshy meadows and floodplain savannas have shown the highest rates of regression. They decreased respectively from 1234 ha in 1986 to 83 ha in 2015, a regression rate of $93 \%$ for mangrove ecosystems, from 63149 ha in 1986 to 6766 ha in 2015 , a regression from $88.90 \%$ for swampy grasslands and from 127454 ha in 1986 to 105233 ha in 2015, representing a $14.49 \%$ regression for flooded savannas. Contrary to this regression dynamics, water plans showed a change in their occupancy from 11217 ha to $43862 \mathrm{ha}$, an increase of $304.97 \%$ between 1986 and 2015;

- Zones with low vegetation cover (mosaics of crops and fallows, urban agglomeration/ bare soil) have indicated an increase in their area in different proportions. It can be deduced that the reserve undergoes an anthropization with an increase in cultivated areas at the rate of $128.64 \%$ and urban agglomeration/ bare soil areas at the rate of $94.93 \%$. The increase in the area of plantations in the reserve (from 13569 ha in 1986 to 19 028 ha or $45.23 \%$ ) is mainly linked to the various reforestation initiatives carried out by different actors such as NGOs /Associations and the ministry in charge of forests but especially the enthusiasm of the people of this region about the restoration of vegetation cover and the need to meet the demand for wood products.

\section{Trajectories of changes in land cover of the reserve between 1986 and 2015}

Superposition of two land cover maps of the RBTM in particular from 1986 to 2000 and from 2000 to 2015 gives a matrix that reflects the evolution of the trajectories of the different classes between the two dates considered.

\section{Changes between 1986 and 2000}

The matrix of changes in land coverland use shows that 4351.41 ha $(56.80 \%)$ of forest (estimated at 7661 ha in 1986) do not undergo noticeable change during the period 1986 to 2000. Of these forest areas, about 3,309.59 ha have been converted to other land uses, of which 293.13 ha are mosaic crops and fallows, and 119.97 ha are part of an urban agglomeration or bare soil (Table 3). Over the same period, 86,373.36 ha of a wetland area of 203,054 ha in $1986(42.54 \%)$ remained unchanged, while $116,680.64$ ha have changed occupancy categories. Forest plantations retained 4801.14 ha $(35.38 \%)$ of their area, while 8767.86 ha changed categories between 1986 and 2000 .

Overall, as shown by the change data for the period 1986 to $2000,49.26 \%$ of the reserve has not undergone major change, which corresponds to 170293.86 ha out of 345722 ha. The remaining area of $175,428.14$ ha $(50.74 \%)$ has undergone changes in occupancy categories. These changes are related to modifications in land use or to conversions to other forms of land use. The changes have mainly occurred in wetlands, particularly between floodplain savannas with $M$. inermis, marshy meadows and water plans. Of all the forms of land use in the reserve, high rates of change have occurred in mangroves $(86.9 \%)$, closed forests $(76.28 \%)$ and water plans $(71.2 \%)$. On the other hand, the lowest rate of change is observed in forest plantations with $1.47 \%$.

\section{Changes between 2000 and 2015}

The superposition of land cover maps from 2000 to 2015 indicates that 3131.01 ha of closed forest remained without major changes, while in the savannas, the area without changes over the same period is estimated at 20,812.59 ha. For these forests, it is noted that a large area is converted to other forms of land use, especially urban agglomerations and bare soil (Table 4). Thus, $3,992.04$ ha of closed forest and 20,897.55 ha of savannas are converted to inhabited areas or areas devoid of vegetation such as bare soil. Similary, with these two forms of land use, an estimated $7,526.43$ ha is converted to crop lands and fallows.

With regard to wetlands, it is noted that 49,724.01 ha are conserved without major 
change during the period 2000 to 2015. For these types of land use, a trend towards urbanization is also observed. As a result, an estimated $14,242.59$ ha is converted to inhabited area and bare soil.

It is noted that the highest rates of change are recorded respectively in inhabited areas and bare soil (91.40\%), wetlands $(89.55 \%$ for marshy meadow, $89.45 \%$ for flooded savannahs with $M$. inermis), plantations $(73.78 \%)$ and closed forest $(72.49 \%)$. Water plans are the least affected land cover and the rate of change is estimated at $3.49 \%$ (Table 4 ).

Table 1: Land cover in the Mono Transboundary Biosphere Reserve in 2015.

\begin{tabular}{|c|c|c|c|}
\hline \multicolumn{2}{|c|}{ Class of land cover/land use } & Area (Ha) & Percentage $(\%)$ \\
\hline \multicolumn{2}{|c|}{$\begin{array}{l}\text { Closed forest (semi-deciduous dense forest, dry } \\
\text { dense forest, open forest and forest gallery) }\end{array}$} & 6835 & 1.98 \\
\hline \multicolumn{2}{|l|}{ Savannahs } & 58919 & 17.04 \\
\hline \multicolumn{2}{|c|}{ Mosaic of crops/fallows } & 89848 & 25.99 \\
\hline \multirow{4}{*}{ Wetlands } & $\begin{array}{l}\text { Floodplain savannas with } \\
\text { Mitragyna inermis }\end{array}$ & 105233 & 30.44 \\
\hline & Marshy meadow & 6766 & 1.96 \\
\hline & Mangroves & 83 & 0.02 \\
\hline & Water plan & 43862 & 12.69 \\
\hline \multicolumn{2}{|c|}{ Plantations } & 19028 & 5.50 \\
\hline \multicolumn{2}{|c|}{ Urban agglomerations/bare soil } & 15148 & 4.38 \\
\hline
\end{tabular}

Table 2: Variation in areas of land cover units in the reserve between 1986 and 2015.

\begin{tabular}{|c|c|c|c|c|c|}
\hline \multicolumn{2}{|c|}{ Classe d'occupation } & $\begin{array}{c}\text { Area in } 1986 \\
\quad(\mathrm{Ha})\end{array}$ & $\begin{array}{c}\text { Area in } 2015 \\
\qquad(\mathrm{Ha})\end{array}$ & $\begin{array}{c}\text { Variation of areas } \\
\text { between } 1986-2015 \\
\text { (Ha) }\end{array}$ & $\begin{array}{l}\text { Rate of change } \\
\text { between 1986- } \\
2015(\%)\end{array}$ \\
\hline \multicolumn{2}{|c|}{ Closed forest } & 7661 & 6835 & -8.26 & -7.61 \\
\hline \multicolumn{2}{|l|}{ Savannas } & 72695 & 58919 & -137.76 & -16.06 \\
\hline \multicolumn{2}{|c|}{ Mosaic of crops/fallows } & 40696 & 89848 & 491.51 & 128.64 \\
\hline \multirow[t]{4}{*}{ Wetlands } & $\begin{array}{l}\text { Floodplain } \\
\text { savanna with } \\
\text { Mitragyna } \\
\text { inermis }\end{array}$ & 127454 & 105233 & -222.21 & -14.49 \\
\hline & Marshy meadow & 63149 & 6766 & -563.83 & -88.90 \\
\hline & Mangrove & 1234 & 83 & -11.50 & -93.00 \\
\hline & Water plan & 11217 & 43862 & 326.45 & 304.97 \\
\hline \multicolumn{2}{|c|}{ Plantations } & 13569 & 19028 & 5459 & 45.23 \\
\hline \multicolumn{2}{|c|}{ Urban agglomeration/ bare soil } & 8048 & 15148 & 71.01 & 94.93 \\
\hline
\end{tabular}




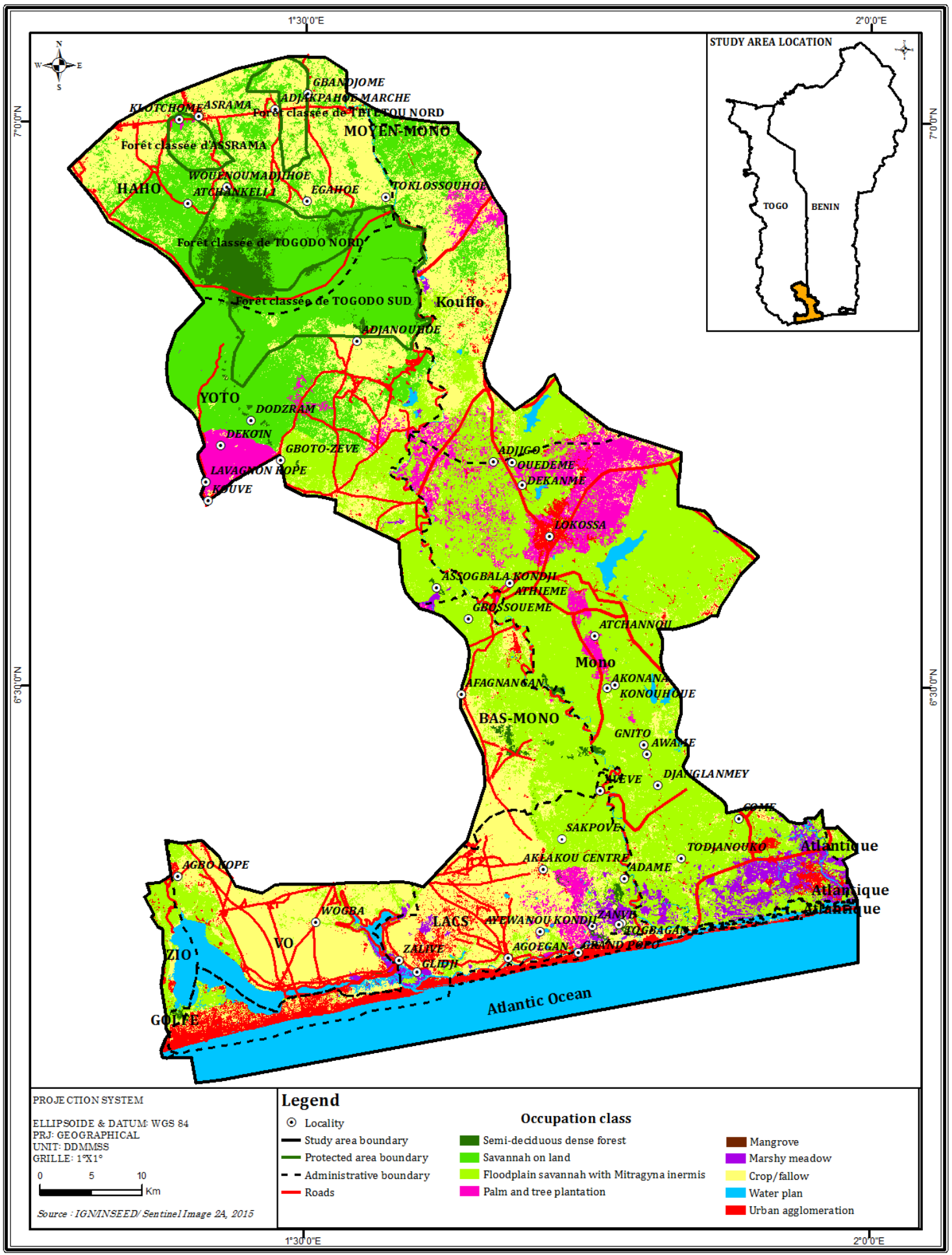

Figure 2: Reference situation of land cover/land use in the Mono Transboundary Biosphere Reserve in 2015 . 


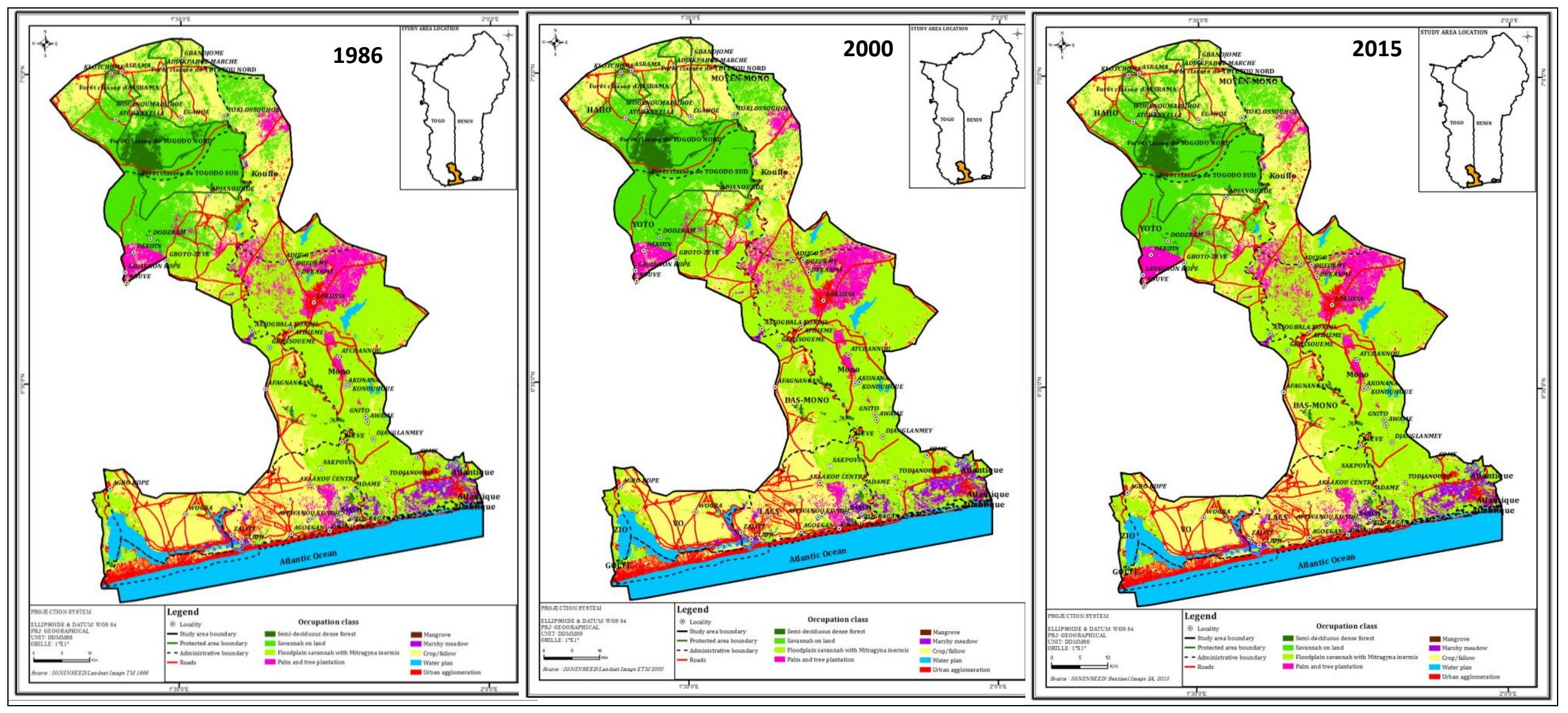

Figure 3: Dynamic of land cover/land use in the Mono Transboundary Biosphere Reserve from 1986 to 2015. 
Table 3: Land occupancy changes matrix from 1986 to 2000.

\begin{tabular}{|c|c|c|c|c|c|c|c|c|c|}
\hline${ }^{2000}$ & $\begin{array}{l}\text { Closed } \\
\text { forest }\end{array}$ & Savannas & $\begin{array}{l}\text { Mosaic of } \\
\text { crops/ } \\
\text { fallows }\end{array}$ & $\begin{array}{l}\text { Floodplain } \\
\text { savannas } \\
\text { with } M \text {. } \\
\text { inermis }\end{array}$ & $\begin{array}{l}\text { Marshy } \\
\text { meadow }\end{array}$ & Mangrove & $\begin{array}{l}\text { Water } \\
\text { plan }\end{array}$ & Plantation & $\begin{array}{l}\text { Urban } \\
\text { agglomeration / } \\
\text { bare soil }\end{array}$ \\
\hline Closed forest & 4351.41 & 762.21 & 293.13 & 4416.21 & 378.18 & 598.95 & 1.53 & 463.14 & 119.97 \\
\hline Savannas & 3099.33 & 37075.95 & 7333.92 & 9052.02 & 5544.54 & 210.42 & 8.64 & 1132.29 & 1841.85 \\
\hline Mosaic of crops/ fallows & 1767.69 & 4108.59 & 28390.32 & 7802.28 & 908.1 & 95.76 & 2.07 & 3307.32 & 5591.52 \\
\hline Floodplain savanna with $M$. inermis & 3680.46 & 1384.11 & 2790.45 & 39273.93 & 1464.66 & 1201.86 & 305.64 & 4792.41 & 1081.35 \\
\hline Marshy meadow & 809.01 & 3370.32 & 851.49 & 10028.07 & 6321.15 & 1179.54 & 36.27 & 16.29 & 1187.91 \\
\hline Mangrove & 375.3 & 320.04 & 643.14 & 3205.62 & 503.37 & 656.64 & 5.94 & 230.85 & 428.13 \\
\hline Water plan & 67.86 & 0.45 & 11.25 & 979.38 & 301.41 & 24.57 & 40121.64 & 4.14 & 401.67 \\
\hline Plantation & 1450.08 & 516.87 & 3431.34 & 9458.55 & 358.92 & 339.48 & 0.09 & 4801.14 & 878.94 \\
\hline Urban agglomeration / bare soil & 2745.81 & 5942.61 & 11284.65 & 33738.21 & 2241.18 & 414.18 & 239.22 & 1902.87 & 9301.68 \\
\hline Total classes $\left(\mathbf{K m}^{2}\right)$ & 18346.95 & 53481.15 & 55029.69 & 117954.27 & 18021.51 & 4721.4 & 40721.04 & 16650.45 & 20833.02 \\
\hline Change in classes $\left(\mathbf{K m}^{2}\right)$ & 13995.54 & 16405.2 & 26639.37 & 78680.34 & 11700.36 & 4064.76 & 599.4 & 11849.31 & 11531.34 \\
\hline Rate of change in classes (\%) & 76.28 & 30.68 & 48.41 & 66.70 & 64.92 & 86.09 & 71.17 & 1.47 & 55.35 \\
\hline
\end{tabular}


Table 4: Land occupancy changes matrix from 2000 to 2015.

\begin{tabular}{|c|c|c|c|c|c|c|c|c|c|}
\hline 2000 & $\begin{array}{l}\text { Closed } \\
\text { forest }\end{array}$ & Savannas & $\begin{array}{l}\text { Mosaic of } \\
\text { crops/ } \\
\text { fallows } \\
\end{array}$ & $\begin{array}{l}\text { Floodplain } \\
\text { Savanna with } \\
\text { M. inermis } \\
\end{array}$ & $\begin{array}{l}\text { Marshy } \\
\text { meadow }\end{array}$ & Mangrove & $\begin{array}{l}\text { Water } \\
\text { plan }\end{array}$ & Plantation & $\begin{array}{l}\text { Urban } \\
\text { agglomeration / } \\
\text { bare soil } \\
\end{array}$ \\
\hline Closed forest & 3131.01 & 2940.39 & 228.15 & 3745.8 & 775.71 & 300.96 & 83.16 & 543.69 & 3992.04 \\
\hline Savannas & 3686.13 & 20812.59 & 7298.28 & 21321.0 & 6690.06 & 2027.07 & 174.69 & 6010.11 & 20897.55 \\
\hline Mosaic of crops/ fallows & 457.02 & 1096.29 & 35503.2 & 5465.16 & 1989.0 & 928.62 & 25.11 & 6847.74 & 18413.91 \\
\hline Floodplain savanna with $M$. inermis & 1799.28 & 11491.65 & 3402.9 & 5903.19 & 7322.22 & 1457.01 & 457.47 & 1240.92 & 8051.13 \\
\hline Marshy meadow & 393.84 & 9608.04 & 256.68 & 1210.68 & 2486.88 & 162.18 & 248.13 & 31.23 & 695.07 \\
\hline Mangrove & 1074.42 & 8335.53 & 2795.13 & 3187.17 & 3788.37 & 886.14 & 288.99 & 671.22 & 4914.90 \\
\hline Water plan & 17.73 & 47.79 & 20.07 & 668.61 & 165.96 & 27.0 & 40447.8 & 3.06 & 581.49 \\
\hline Plantation & 769.5 & 58.37 & 1197.63 & 14104.17 & 46.71 & 403.29 & 6.93 & 5567.94 & 4432.59 \\
\hline Urban agglomeration / bare soil & 55.8 & 509.31 & 1271.61 & 369.09 & 535.14 & 176.76 & 180.09 & 319.5 & 5831.73 \\
\hline Total classes $\left(\mathrm{Km}^{2}\right)$ & 11384.73 & 65298.96 & 51973.65 & 55974.87 & 23800.05 & 6369.03 & 41912.37 & 21235.41 & 15765.92 \\
\hline Change in classes $\left(\mathrm{Km}^{2}\right)$ & 8253.72 & 44486.37 & 16470.45 & 50071.68 & 21313.17 & 5482.89 & 1464.57 & 15667.47 & 61978.68 \\
\hline Rate of change in classes $(\%)$ & 72.49 & 68.13 & 31.69 & 89.45 & 89.55 & 86.09 & 3.49 & 73.78 & 91.40 \\
\hline
\end{tabular}




\section{DISCUSSION}

The processing of Landsat (TM (1986) and ETM + (2000)) and Sentinel 2A (2015) satellite images and other geographic information's allowed to establish the baseline of the study area for a better knowledge of land use patterns, ecosystems and habitats. The method used to analyze the transition modalities between the different dates is based on post-classification processing. This approach appears to be a robust method with respect to variations in image quality (Lefèvre et al., 2002; Rigollier et al., 2004; Corgne, 2014). Thus, in the context of this study, it allowed to perform an analysis of images from different sensors (Landsat and Sentinel 2A). The results obtained provide sufficient evidence that satellite data and remote sensing are tools for mapping land cover transformations by providing spatially explicit information (Cabral and Lagos, 2017; Hagensiekera et al., 2017; Ramachandrana et al., 2018).

The analysis of land cover and its evolution dynamics allow to understand the biophysical and anthropic processes which direct the quantitative and qualitative evolution of landscapes in a general way and natural resources in particular, including vegetation cover, water and soils (Davranche et Taïbi, 2015). But this analysis also seeks to understand and highlight the factors, both natural and anthropogenic, that cause these processes. Thus, the analysis of the dynamics of change in land cover units in the RBTM revealed the different evolutionary processes that took place in the landscape during the period 1986 - 2015. These changes mainly concern the regression of closed forest and wooded savannas, while low-cover soil occupancy (mosaics of crops and fallows and urban agglomerations / bare soil) have shown a gradual increase in their areas. These results are consistent with those of Avakoudjo et al. (2014) in the W National Park and its periphery in north-western Benin, which show a continuous regression of forests in favour of fallows, bare soil and settlements based on diachronic studies.

This shows that the RBTM is characterized by high pressures on the dynamics of land use. It must be noted that the phenomenon of ecosystem degradation has become more pronounced from 2000 to 2015 with a greater anthropization of forest domains and wooded savannas and their conversion to cultivated areas, inhabited areas / bare soils. The factors most commonly cited as having contributed greatly to reductions in forest areas and savannas are agricultural practices, logging, charcoal production and wildfires. The manifestations of these factors are more and more felt with the everincreasing population of the area, thus increasing resource needs and accentuating pressure on land (Adjonou et al., 2013). Conversions of natural forests into agricultural and non-vegetated areas observed in the RBTM are common and support earlier work on changes in land use (Ouedraogo et al., 2010; Houessou et al., 2013; Brandt et al., 2014; Faye et Cheikh, 2016; Konko et al., 2018a). This trend in reduced natural vegetation cover in West Africa is an urgent environmental concern as it leads to soil and ecosystem degradation (Avajoudjo et al., 2014; Faye et Cheikh, 2016; Zoungrana et al., 2018). It is to address these concerns that in recent decades conservation science has increasingly incorporated work on changes in land use as simple processes, reduced to the manifestation of an irreversible transition from one state to another (Mertens and Lambin, 2000).

Contrary to the regressive dynamics of natural forest landscapes, increase in the area of anthropophilic landscapes is linked to the degradation of forests and savannas. The most dramatic increase is observed with size of water bodies having an estimated rate of $304.97 \%$ representing an increase in area of about 32645 ha. This increase in the surface area of the water plans would be globally linked to the recurring flood phenomena that the area has known in recent years. The interannual rainfall variability would therefore be the main cause as we can have an increase in temporary water areas and floodplains because of a year of good rainfall.

The degradation of the environment resulting from the regression of natural forest landscapes is linked to the development of socio-economic activities (slash-and-burn agriculture, exploitation of timber, charcoal 
production mining, etc.) in a context of demographic pressure (Pale, 2000). Several authors have questioned population growth and certain modes of exploitation as the causes of ecosystem and land degradation resulting in the disruption of ecological balances (Konko et al., 2018b). This is a remarkable phenomenon in sub-Saharan Africa, where high population densities and the crisis of agricultural space lead people to seek new land (Abotchi, 2002). Indeed, the area of the reserve is marked by high population density estimated at 300 to 350 inhabitants $/ \mathrm{km}^{2}$ and the agricultural practices adopted by the populations lead farmers to exploit more fertile forest lands and marginal lands in wetlands (Adjonou et al., 2013). Thus, to meet the growing needs for land, people are exploiting fertile forest lands available in the protected areas. In a similar study conducted in Côte d'Ivoire, Kouassi (2014) argues that forest reduction can also be explained by the type of agriculture practiced. The author explains that predominantly agricultural areas where there is a continual search for more productive land, farmers abandon cultivated lands after one or two years of exploitation, to colonize new more fertile forest lands, leaving the former fallow to restore fertility.

Although changes in land use in the RBTM provide social and economic benefits at several levels, especially for the well-being of the population, it should be noted that land development is responsible for ecological degradation at different spatial scales. In this regard, it has been shown that the different phases of economic development (agricultural, industrial, etc.) affect different components of biodiversity over time. The agricultural phase tends, to eliminate the biodiversity of highly productive areas, while preserving the marginal areas (Pale, 2000 ; Davranche et Taïbi, 2015). But these biodiversity reservoirs are now threatened by recreational activities or residential spaces that are spreading to rural areas. Increasingly, land-use changes are taking place over large areas, to the detriment of residual biodiversity. This degradation usually results in the reduction of ecosystem services provided. A study conducted in the peripheral zone of the
RBTM in 2016, shows that the populations perceive the decline in services provided by the reserve in the following proportions: $64.4 \%$ for wood energy, $54 \%$ for wood products, $44.4 \%$ for bush meat and $78.9 \%$ for agricultural products. For these populations, the different proportions of decline are related to the excessive extraction of forest resources, demographic pressure, and climate-related changes, particularly long periods of drought (GIZ, 2016).

However, it should be noted that despite the changes and conversions observed during the period of this study (1986 to 2015), the study area remained largely covered with natural vegetation and still has good potential for the conservation of biodiversity. The reserve is rich in plant and animal resources associated with a diverse multi-function ecosystem. Thus, the better preserved natural habitats consist of semi-deciduous forests, wooded savannas, flooded savannas and associated ecosystems, mangroves, etc.; some of these are still found in the Togodo protected complex, in the community forests (Akissa, Godje-Godjin) and in the lagoonal system along the coast of south-east Togo. The preservation of these habitats will allow the conservation of biological diversity (Abdourhamane et al., 2013; Faye et al., 2018) and also the reinforcement of the resilience of populations in facing the harmful effects of climate change. To this end, the development of the land use baseline in this study provides quantitative data and information (occupancy / use classes, area estimates) needed for good land use to describe and establish a quantitative link between human activities, their impact on the environment, and the geographical (spatial) dimension. Information on the dynamics of land use incorporating the temporal dimension is therefore of great importance to decision-makers who evaluate decisions on the use of natural resources and to the scientific community that discovers the causes and the effects of land use changes on the management of the natural resources of the RBTM.

\section{Conclusion}

The reference situation of the RBTM between Togo and Benin in terms of land 
cover and land use is established on a scientific basis using satellite images and other sources of geographical information. The results of this satellite image analysis allowed a better knowledge of the types of land occupancy, the ecosystems, the habitats and the dynamics of change in the RBTM. The analysis of the dynamics of change in land occupancy units revealed the different processes of evolution within the landscape during the period 1986 - 2015. These changes mainly concern the regression of natural ecosystems such as closed forests and wooded savannas whereas low-cover land occupancies (mosaics of crops / fallows and urban agglomerations / bare soil) have been gradually increasing. Despite the changes and conversions observed during the period of this study (1986 to 2015), the study area remained largely covered with natural vegetation and still has good potential for biodiversity conservation. The reserve is rich in important plant and animal resources associated with a diverse multi-function ecosystem. The preservation of these habitats will allow conservation of biological diversity but also the reinforcement of the resilience of the population in the face of the harmful effects of climate change. All the information generated by this study should be of interest to policymakers, NGOs and the scientific community who evaluate decisions on the use of natural resources. The study therefore provides information for applications ranging from land use planning, forest cover monitoring and production of environmental statistics.

\section{COMPETING INTERESTS}

The authors declare that they have no competing interests.

\section{AUTHOR CONTRIBUTIONS}

All authors contribute significantly to the present study and to the revision of the manuscript. KA: conceived and designed the experiments, performed the experiments, analyzed and interpreted the data, materials, analysis tools or data, wrote the paper; IA$\mathrm{KB}$ : conceived and designed the experiments, performed the experiments, analyzed and interpreted the data, materials, analysis tools or data, wrote the paper; KNS: conceived and designed the experiments, performed the experiments, materials, analysis tools or data, wrote the paper; IR: conceived and designed the experiments, performed the experiments, analyzed and interpreted the data, wrote the paper; KVS: conceived and designed the experiments, performed the experiments; RG$\mathrm{K}$ : conceived and designed the experiments, analyzed and interpreted the data; KK: conceived and designed the experiments, performed the experiments, analyzed and interpreted the data, wrote the paper.

\section{REFERENCES}

Abdourhamane $\mathrm{H}$, Morou B, Rabiou $\mathrm{H}$, Mahamane A. 2013. Caractéristiques floristiques, diversité et structure de la végétation ligneuse dans le centre-sud du Niger : cas du complexe des forêts classées de Dan Kada Dodo-Dan Gado. Int. J. Biol. Chem. Sci., 7(3): 1048-1068. DOI: http://dx.doi.org/10.4314/ijbcs. v7i3.13.

Abotchi T. 2002. Colonisation agricole et dynamique de l'espace rural au Togo: cas de la plaine septentrionale du Mono. Revue du C.A.M.E.S. Sciences Sociales et Humaines. Série B., 4(2): 97-108.

Achard F, Eva HD, Stibig HJ, Mayaux P, Gallego J, Richards T, Malingreau JP. 2002. Determination of deforestation rates of the world's humid tropical forests. Science, 297(5583): 999-1002. DOI: $10.1126 /$ science. 1070656.

Adjonou K, Kémavo A, Fontodji JK, Tchani W, Sodjinou F, Sebastia MT, Kokutse AD, Kokou K. 2017. Vegetation dynamics patterns, biodiversity conservation and structure of forest ecosystems in the wildlife reserve of Togodo in Togo, West Africa. International Journal of Development Research, 7(08): 14549-14557. http://www.journalijdr.com.

Adjonou K, Kokutse AD, Kokou K. 2013. Dynamique spatiale et diversité floristique de la Réserve de Faune de Togodo au Sud Est du Togo (Afrique de l'Ouest). Scripta Botanica Belgica, 50: 63-72.

Agbessi GE, Ouedraogo M, Camara M, Segniagbeto H, Houngbedji MB, Kabre 
AT. 2017. Distribution spatiale du singe à ventre rouge, Cercopithecus erythrogaster erythrogaster Gray et les menaces pesant sur sa conservation durable au Togo. Int. J. Biol. Chem. Sci., 11(1): 157-173. DOI: http://dx.doi.org/10.4314/ijbcs.v11i1.13.

Akobi KI, Amoussou E, Yabi I, Boko M. 2018. Historique de l'évolution anthropique et dynamique du couvert végétal dans la commune de Bantè au Bénin. Int. J. Biol. Chem. Sci., 12(1): 180-194.

DOI: https://dx.doi.org/10.4314/ijbcs.v12i1.14

Avakoudjo J, Mama A, Toko I, Kindomihou V, Sinsin B. 2014. Dynamique de l'occupation du sol dans le Parc National du W et sa périphérie au Nord-Ouest du Bénin. Int. J. Biol. Chem. Sci., 8(6): 2608-2625.

DOI: http://dx.doi.org/10.4314/ijbcs.v8i6.22.

Bouko BS, Sinsin B, Goura Soulé B. 2007. Effets de la dynamique d'occupation du sol sur la structure et la diversité floristique des forêts claires et savanes au Bénin. Tropicultura, 25(4): 221-227.

Bounoua L, DeFries R, Collatz GJ, Sellers P, Khan H. 2002. Effects of Land Cover Conversion on Surface Climate. Climatic Change, 52(1): 29-64. DOI: 10.1023/A:1013051420309.

Brandt M, Grau T, Mbow C, Samimi C. 2014. Modeling Soil and Woody Vegetation in the Senegalese Sahel in the Context of Environmental Change. Land, 3(3): 770792. DOI: $10.3390 /$ land 3030770.

Cabral AIR, Lagos CF. 2017. Land cover changes and landscape pattern dynamics in Senegal and Guinea Bissau borderland. Applied Geography, 82: 115128.

DOI: 10.1016/j.apgeog.2017.03.010.

Clerici N, Bodini A, Eva H, Grégoire JM, Dulieu D, Paolini C. 2007. Increased isolation of two Biosphere Reserves and surrounding protected areas (WAP ecological complex, West Africa). Journal for Nature Conservation, 15(1): 26-40.

DOI: https://doi.org/10.1016/j.jnc.2006.08.003

Corgne S. 2014. Étude des changements d'occupation et d'usage des sols en contexte agricole par télédétection et fusion d'informations. Géographie. Université Rennes, 2(1): 138p. https://hal.archives-ouvertes.fr/tel01240394.

Davranche A, Taïbi AN. 2015. Les changements d'occupation et d'usage du sol, des processus multidimensionnels complexes qui affectent la biodiversité. Mathevet R.; Godet L. Pour une géographie de la conservation, L'Harmattan, 978-2-34306972-2. https://hal.archivesouvertes.fr/hal-01226543.

Dube T, Mutanga O. 2015. Investigating the robustness of the Landsat- 8 sensor derived texture parameters in estimating plantation forest species aboveground biomass in KwaZulu-Natal, South Africa. Journal of Photogrametry and Remote Sensing, 108: 12-32. DOI: 10.1016/j.isprsjprs.2015.06.002.

FAO, 1996. Forest resources assessment 1990 - Survey tropical forest cover studies of change processes. FAO Forestry Paper 130, Food and Agriculture Organization of United Nations, Rome, Italie. http://www.fao.org/docrep/007/w0015e/ w0015e00.htm.

Faye VMM, Cheikh TA. 2016. Évolution de l'occupation et de l'utilisation du sol entre 1973 et 2010 dans la zone agropastorale du lac de Guiers (Sénégal). VertigO. DOI: 10.4000/vertigo.17206.

Faye B, Bassene C, Camara AA, Ngom A, Mbaye MS, Noba K. 2018. Flore et végétation de la Réserve Spéciale de Faune de Gueumbeul (Sénégal). Int. J. Biol. Chem. Sci., 12(1): 43-61. DOI: https://dx.doi.org/10.4314/ijbcs.v12i1.4.

Girard MC, Girard CM. 1999. Traitement des Données de Télédétection. Dunod : Paris, France, $529 \mathrm{p}$.

GIZ, 2016. Evaluation de la situation socioéconomique, du cadre de gouvernance, du genre et de l'accès aux ressources dans les aires cibles de la RBT-DM. Rapport final, $144 \mathrm{p}$.

Hagensiekera R, Roscher R, Rosentretera J, Jakimow B, Waske B. 2017. Tropical land use land cover mapping in Pará (Brazil) using discriminative Markov random fields and multi-temporal TerraSAR-X data. Int. J. Appl. Earth 
Obs Geoinformation, 63: 244-256. DOI : 10.1016/j.jag.2017.07.019.

Houessou LG, Teka O, Toko II, Lykke AM, Sinsin B. 2013. Land Use and LandCover Change at "W" Biosphere Reserve and Its Surroundings Areas in Benin Republic (West Africa). Environment and Natural Resources Research, 3(2): $87 \quad-\quad 101 . \quad$ DOI: http://dx.doi.org/10.1016/j.jaridenv.2004 .03 .022 .

Hougbédji BM, Djossa BA, Adomou AC, Dakpogan C, Sinsin B, Mensah GA. 2012. Conservation Status of the Redbellied Guenon (Cercopithecus erythrogaster erythrogaster) in the West Dahomey Gap in Southwestern Benin and the Adjacent Togodo Forest Reserve, South Togo. African Primates, 7(2): 184-192. DOI: http://www.academia.edu/3836024.

Kamungandu CM. 2009. Etudes de cas sur l'évaluation de la dégradation des forêts : La dégradation des forêts en République Démocratique du Congo. Evaluation des ressources forestières. Document de travail 169, Rome : FAO.

Kokou K, Sokpon N. 2006. Les forêts sacrées du couloir du Dahomey. Bois et Forêts des Tropiques, 288(2): 15-23. DOI: https://doi.org/10.19182/bft2006.288.a20 312.

Konko Y, Bagaram B, Julien F, Akpamou KG, Kokou K. 2018a. Multitemporal Analysis of Coastal Erosion Based on Multisource Satellite Images in the South of the Mono Transboundary Biosphere Reserve in Togo (West Africa). Open Access Library Journal, 5(4): 1-21. DOI: 10.4236/oalib.1104526.

Konko Y, Rudant JP, Akpamou KG, Noumonvi KD, Kokou K. 2018b. SpatioTemporal Distribution of Southeastern Community Forests in Togo (West Africa). Journal of Geoscience and Environment Protection, 6: 51 - 65. DOI: $10.4236 /$ gep.2018.67004.

Kouassi KJL, 2014. Suivi de la dynamique de l'occupation du sol à l'aide de l'imagerie satellitaire et des systèmes d'information géographiques: Cas de la Direction Régionale des Eaux et Forêts de Yamoussoukro (Côte d'Ivoire). Mémoire pour l'option du Diplôme d'Agronomie Approfondie, Ecole Supérieure d'Agronomie, Côte d'Ivoire ; 74 p.

Kpedenou KD, Boukpessi T, Tchamie TTK. 2016. Quantification des changements de l'occupation du sol dans la préfecture de Yoto (Sud-Est Togo) à l'aide de l'imagerie satellitaire Landsat. Revue des Sciences de l'Environnement, 13 : 137156. https://hal.archives-ouvertes.fr/hal01409418.

Lefèvre M, Albuisson M, Wald L. 2002. Description of the software Heliosat-2 for the conversion of images acquired by Meteosat satellites in the visible band into maps of solar radiation available at ground level. Report available at www.helioclim.org/heliosat, $42 \mathrm{p}$.

Liu YI, Chang MV, Li HE, Barolo S, Chang JL, Blauwkamp TA, Cadigan KM. 2008. The chromatin remodelers ISWI and ACF1 directly repress Wingless transcriptional targets. Dev. Biol. 323(1): 41-52.

DOI: 10.1016/j.ydbio.2008.08.011.

Mertens B, Lambin EF. 2000. Land-CoverChange Trajectories in Southern Cameroon. Annals of the Association of American Geographers, 90: 467-494. https://doi.org/10.1111/00045608.00205 .

Minta M, Kibretb K, Thorne P, Nigussie T, Nigatu L. 2018. Land use and land cover dynamics in Dendi-Jeldu hillymountainous areas in the central Ethiopian highlands. Geoderma, 314 : 27-36.

DOI: https://dx.doi.org/10.1016/j.geoderma.20 17.10.035.

Muriuki GW, Seabrook L, Mcalpine C, Baxter GS. 2011. Land cover change under unplanned human settlements: A study of the Chyulu Hills squatters, Kenya. Landscape and Urban Planning, 99(2): 154-165.

DOI: 10.1016/j.landurbplan.2010.10.002.

Oloukoi J, Mama VJ, Agbo FB. 2006. Modélisation de la dynamique de l'occupation des terres dans le Département des Collines au Bénin. Télédétection, 6(4): 305-323.

Ouedraogo I, Tigabu M, Savadogo P, Compaore H, Oden PC, Ouadba JM. 
2010. Land cover change and its relation with population dynamics in Burkina Faso, West Africa. Land Degrad. Dev. 21: 453-462. DOI: http://dx.doi.org/10.1002/ldr.981

Padonou EA, Lykke AM, Bachmann Y, Idohou R, Sinsin B. 2017. Mapping changes in land use/land cover and prediction of future extension of bowé in Benin, West Africa. Land Use Policy, 69: 85-92. DOI:

http://dx.doi.org/10.1016/j.landusepol.20 17.09.015.

Pale FOK. 2000. Le rôle de l'action anthropique dans la dégradation des ressources naturelles à NiaoghoBeguedo. Berichte des Sonderforschungsbereichs, $\quad \mathbf{2 6 8}(14)$ : 521-533.

Ramachandrana RM, Sarathi RP, Chakravarthia V, Sanjayb J, Pawan KJ. 2018. Long-term land use and land cover changes (1920-2015) in Eastern Ghats, India: Pattern of dynamics and challenges in plant species conservation. Ecological Indicators, 85: 21-36. DOI : https://doi.org/10.1016/j.ecolind.2017.10 .012 .

Rigollier C, Lefèvre M, Wald L. 2004 The method Heliosat-2 for deriving shortwave solarradiation from satellite images. Solar Energy, 77(2) : 159-169. DOI: 10.1016/j.solener.2004.04.017.

Sarr MA. 2009. Cartographie des changements de l'occupation du sol entre 1990 et 2002 dans le nord du Sénégal (Ferlo) à partir des images Landsat, Cybergeo : European Journal of
Geography, Environnement, Nature, Paysage, document 472. http://journals.openedition.org/cybergeo/ 22707; DOI: 10.4000/cybergeo.22707.

Schlaepfer MA, Runge MC, Sherman PW. 2002. Ecological and evolutionary traps. Trends in Ecology and Evolution, 17: 474-480. DOI: $10.1016 / \mathrm{S} 0169$ 5347(02)02580-6.

Sibanda N, McKenna A, Richmond A, Ricke SC, Callaway T, Stratakos AC, Gundogdu O, Corcionivoschi N. 2018. A Review of the Effect of management practices on Campylobacter Prevalence in Poultry Farms. Frontiers in Microbiology, $9 . \quad$ DOI: https://doi.org/10.3389/fmicb.2018.0200 2.

Skupinski G, Binthtran D, Weber C. 2009. Les images satellites Spot multi-dates et la métrique spatiale dans l'étude du changement urbain et suburbain - Le cas de la basse vallée de la Bruche (BasRhin, France). Cybergeo : European Journal of Geography; Document 439. DOI: 10.4000/cybergeo.21995.

World Bank. 2017. Réserve de Biosphère transfrontalière du Delta du Mono: Etude de cas $1 ; 5 \mathrm{p}$.

Zoungrana BJB, Conrad C, Thiel M, Amekudzi LK, Dapola Da E. 2018. MODIS NDVI trends and fractional land cover change for improved assessments of vegetation degradation in Burkina Faso, West Africa. Journal of Arid Environments 153: 66-75. DOI: https://doi.org/10.1016/j.jaridenv.2018.0 1.005 . 